\title{
ANALISIS KINERJA MAHASISWA DALAM PRAKTIKUM ISOLASI DNA
}

\author{
Evi Suryanti*1, Dara Mutiara Aswan² \\ ${ }^{1}$ Pendidikan Biologi FKIP Universitas Islam Riau, J1. Kaharuddin Nasution No. 113, Perhentian \\ Marpoyan, Pekanbaru, Riau \\ ${ }^{2}$ Pendidikan Biologi FKIP Universitas Jambi, Kampus Pinang Masak, Jl. Raya Jambi-Muara Bulian \\ Km. 15, Mendalo Indah, Muaro Jambi, Jambi \\ e-mail: *1evibio@edu.uir.ac.id, ${ }^{2}$ daramutiaraaswan@gmail.com
}

\begin{abstract}
ABSTRAK
Praktikum merupakan fitur penting dalam pendidikan sains. Praktikum membantu pelajar untuk mengembangkan pemahaman tentang sains, menghargai bahwa sains itu berdasarkan bukti, dan melalui praktikum pelajar dapat memperoleh keterampilan hands-on secara langsung. Penelitian bertujuan untuk mengeksplorasi kinerja praktikum dari 26 orang mahasiswa Program Studi Pendidikan Biologi pada salah satu LPTK swasta di Kota Pekanbaru dalam praktikum mengisolasi DNA bakteri Escherichia coli. Instrumen penelitian berupa rubrik kinerja praktikum yang disusun berdasarkan tahapan kerja dalam mengisolasi DNA dengan fasilitas praktikum yang terbatas. Rubrik kinerja praktikum terdiri dari tiga aspek (persiapan praktikum, pelaksanaan praktikum, dan kegiatan akhir praktikum). Ketiga aspek tersebut diuraikan menjadi delapan sub-aspek yaitu perlengkapan keselamatan, rancangan praktikum, penggunaan sentrifus, penggunaan vortex, penggunaan pipet mikro dan tip, pengambilan bahan kimia/reagen, partisipasi selama praktikum, dan penutup praktikum. Data skor kinerja dikumpulkan dengan metode observasi terhadap aktivitas mahasiswa selama praktikum berlangsung dengan menggunakan rubrik kinerja tersebut. Skor kinerja dikonversikan ke dalam bentuk persentase lalu diinterpretasikan menjadi kinerja praktikum berdasarkan kategori yang ditetapkan. Berdasarkan hasil analisis data diperoleh rerata persentase kinerja praktikum mahasiswa pada topik isolasi DNA sebesar 97,23\% dengan kriteria 'sangat baik'.
\end{abstract}

Kata Kunci : Biologi molekuler, isolasi DNA, kinerja praktikum.

\begin{abstract}
Practicum is an important feature in science education. Practicum helps students to develop an understanding of science, appreciate that science is based on evidence, and through practicum students can acquire hands-on skills directly. The research aimed to explore the practical performance of 26 students of the Biology Education Study Program at one of the private LPTKs in Pekanbaru City in practicing isolating the DNA of the Escherichia coli bacteria. The research instrument was in the form of a practicum performance rubric which was arranged based on the work stages in isolating DNA with limited practicum facilities. The practicum performance rubric consists of three aspects (practicum preparation, practicum implementation, and practicum final activity). The three aspects are described into eight sub-aspects, namely safety equipment, practicum design, use of centrifuges, use of vortices, use of micro pipettes and tips, collection of chemicals / reagents, participation during practicum, and practicum cover. The performance score data was collected using the observation method of student activities during the practicum using the performance rubric. The performance score is converted into a percentage and then interpreted into practicum performance based on the defined categories. Based on the results of data analysis, the
\end{abstract}


average percentage of student practicum performance on the topic of DNA isolation was $97.23 \%$ with the criteria "very good".

Keywords: Molecular biology, DNA isolation, practicum performance.

\section{PENDAHULUAN}

DNA merupakan molekul asam nukleat beruntai-ganda dan berbentuk heliks yang tersusun dari monomer-monomer nukleotida dengan gula deoksiribosa; mampu bereplikasi dan menentukan struktur terwariskan dari protein-protein suatu sel (Campbell dan Reece, 2010). DNA dapat diisolasi, diamplifikasi, dan dianalisis untuk berbagai tujuan seperti mengidentifikasi pelaku kejahatan atau alat untuk identifikasi forensik, mengidentifikasi tanaman atau menentukan hubungan genetik. DNA ditemukan di dalam inti sel organisme eukariotik. DNA harus diisolasi terlebih dahulu sebelum digunakan untuk berbagai tujuan analisis pada tingkat molekuler (Fatchiyah, et al., 2011).

Isolasi DNA merupakan salah satu topik yang dibahas pada matakuliah pilihan biologi molekuler. Mahasiswa dapat mempelajari tentang teori dan prinsip dari isolasi DNA serta teknik atau metode untuk mengisolasi DNA dari sampel jaringan atau mikroorganisme. Teknik mengisolasi DNA akan lebih dapat dipahami oleh mahasiswa dengan cara melakukan kerja praktikum secara langsung (hands-on). Sesuai dengan pendapat peneliti sebelumnya bahwa lingkungan pembelajaran hands-on dan berpusat-aktivitas lebih banyak dibutuhkan oleh pelajar (Glowinski dan Bayrhuber, 2011), dan kerja praktik di laboratorium merupakan salah satu elemen penting dari pendidikan sains (Membiela dan Vidal, 2017). Manfaat kegiatan laboratorium bagi pelajar untuk meningkatkan: pemahaman prosedural dan konseptual, keterampilan intelektual dan praktis, serta literasi ilmiah (Areepattamannil, et al., 2011), dan aktivitas kerja praktik dapat digunakan sebagai alat asesmen untuk mengases pengetahuan dan keterampilan pelajar secara simultan (Sedumedi, 2017).

Praktikum (practical work) merupakan aktivitas di mana para pelajar memanipulasi dan mengamati benda dan obyek nyata. Guru dan ilmuwan berpendapat bahwa praktikum dalam sains sekolah merupakan pusat daya tarik pendidikan sains (Abrahams dan Millar, 2008). The House of Commons Science and Technology Committee dalam Abrahams dan Millar (2008) menyatakan praktikum (termasuk kerja lapangan) sebagai bagian penting dari pendidikan sains yang membantu pelajar untuk mengembangkan pemahaman tentang sains, menghargai sains berdasarkan bukti, dan dapat memperoleh keterampilan langsung (hands-on activity). Hasil penelitian Cerini, et al., (2003) mengungkapkan pendapat pelajar bahwa praktikum relatif bermanfaat, menyenangkan, dan efektif dibandingkan dengan kegiatan belajar mengajar sains lainnya. Uraian di atas menjelaskan pentingnya praktikum dan seharusnya diterapkan dalam pembelajaran biologi. Praktikum mengisolasi DNA dari kultur bakteri Escherichia coli dalam pembelajaran biologi molekuler telah dilakukan, dan kinerja mahasiswa diases dengan menggunakan rubrik kinerja pada saat praktikum tersebut berlangsung. Tujuan penelitian adalah untuk mengetahui kinerja mahasiswa dalam praktikum mengisolasi DNA.

\section{METODE}

Penelitian deskriptif dengan metode observasi diterapkan dalam penelitian ini. Subyek penelitian adalah mahasiswa Program Studi Pendidikan Biologi di salah satu LPTK di Kota Pekanbaru yang berjumlah 26 orang mahasiswa yang hadir pada saat praktikum. Adapun jumlah mahasiswa yang mengontrak matakuliah pilihan biologi molekuler pada Semester Genap Tahun akademik 2018/2019 sebanyak 29 orang (28 orang perempuan dan 1 orang laki-laki). 
Instrumen penelitian yang digunakan berupa rubrik kinerja praktikum. Rubrik dibuat berdasarkan prosedur umum dalam isolasi DNA yang ditelaah dari literatur dan disesuaikan dengan fasilitas laboratorium yang tersedia untuk praktikum isolasi DNA. Selanjutnya rubrik divalidasi oleh empat orang dosen ahli dalam pembelajaran biologi dan satu orang dosen ahli dalam biologi molekuler. Validasi yang dilakukan adalah validasi logis meliputi validasi isi dan konstruksi. Rubrik direvisi berdasarkan saran dari para validator. Rubrik kinerja praktikum yang digunakan dapat dilihat pada Tabel 1.

Tabel 1. Rubrik Penilaian Kinerja Praktikum Isolasi DNA

\begin{tabular}{|c|c|c|c|c|}
\hline Aspek & Sub-aspek & Skor & Kriteria Penskoran & $\begin{array}{l}\text { Skor } \\
\text { Maks }\end{array}$ \\
\hline \multirow{2}{*}{$\begin{array}{l}\text { Persiapan } \\
\text { praktikum }\end{array}$} & $\begin{array}{l}\text { Perlengkapan } \\
\text { keselamatan }\end{array}$ & $\begin{array}{l}2 \\
1\end{array}$ & $\begin{array}{l}\text { - Menggunakan jas laboratorium } \\
\text { - Menggunakan sarung tangan } \\
\text { - Rambut tertutup atau tertata dengan rapi } \\
\text { Bila } 2 \text { kriteria terpenuhi } \\
\text { Bila } 1 \text { kriteria terpenuhi }\end{array}$ & 3 \\
\hline & $\begin{array}{l}\text { Rancangan } \\
\text { praktikum }\end{array}$ & 2 & $\begin{array}{l}\text { - Memiliki rancangan praktikum } \\
\text { - Ada "coretan/tanda bacaan" pada kertas } \\
\text { rancangan praktikum tersebut } \\
\text { Bila } 1 \text { kriteria terpenuhi }\end{array}$ & 2 \\
\hline \multirow{5}{*}{$\begin{array}{l}\text { Pelaksanaan } \\
\text { praktikum }\end{array}$} & $\begin{array}{l}\text { Penggunaan } \\
\text { sentrifus }\end{array}$ & $\begin{array}{l}3 \\
2 \\
1\end{array}$ & $\begin{array}{l}\text { - Menyeimbangkan volume tabung mikro } \\
\text { yang akan disentrifus } \\
\text { - Mengatur jumlah dan posisi tabung mikro } \\
\text { agar seimbang } \\
\text { - Merapatkan penutup sentrifus } \\
\text { - Memastikan sentrifugasi selesai sebelum } \\
\text { membuka penutupnya } \\
\text { Bila } 3 \text { kriteria terpenuhi } \\
\text { Bila } 2 \text { kriteria terpenuhi } \\
\text { Bila } 1 \text { kriteria terpenuhi }\end{array}$ & 4 \\
\hline & $\begin{array}{l}\text { Penggunaan } \\
\text { vortex }\end{array}$ & $\begin{array}{l}2 \\
1\end{array}$ & $\begin{array}{l}\text { - Memastikan tabung mikro yang akan } \\
\text { divortex tertutup rapat } \\
\text { - Meletakkan tabung mikro pada permukaan } \\
\text { bagian karet } \\
\text { - Mengetahui dengan pasti berapa lama } \\
\text { sampel divortex } \\
\text { Bila } 2 \text { kriteria terpenuhi } \\
\text { Bila } 1 \text { kriteria terpenuhi }\end{array}$ & 3 \\
\hline & \multirow[t]{3}{*}{$\begin{array}{l}\text { Penggunaan } \\
\text { pipet mikro } \\
\text { dan tip }\end{array}$} & 6 & $\begin{array}{l}\text { - Mengambil pipet dengan ukuran yang sesuai } \\
\text { - Memegang pipet dengan arah dan cara yang } \\
\text { benar } \\
\text { - Mengambil tip sesuai dengan ukuran pipet } \\
\text { yang digunakan } \\
\text { - Memasangkan tip ke pipet dengan cara yang } \\
\text { benar } \\
\text { - Memipet larutan dengan cara yang benar } \\
\text { - Melepaskan/membuang tip dengan cara yang } \\
\text { benar }\end{array}$ & \multirow[t]{3}{*}{6} \\
\hline & & 5 & Bila 5 kriteria terpenuhi & \\
\hline & & 4 & Bila 4 kriteria terpenuhi & \\
\hline
\end{tabular}




\begin{tabular}{|c|c|c|c|c|}
\hline & & $\begin{array}{l}3 \\
2 \\
1\end{array}$ & $\begin{array}{l}\text { Bila } 3 \text { kriteria terpenuhi } \\
\text { Bila } 2 \text { kriteria terpenuhi } \\
\text { Bila } 1 \text { kriteria terpenuhi }\end{array}$ & \\
\hline & $\begin{array}{l}\text { Pengambilan } \\
\text { bahan kimia } \\
\text { (reagen) }\end{array}$ & 4 & $\begin{array}{l}\text { - Terlebih dahulu membuka tutup botol } \\
\text { reagen dengan benar } \\
\text { - Mengambil reagen dengan tertib } \\
\text { (tidak ada ceceran atau tumpahan) } \\
\text { - Mengetahui dengan pasti takaran reagen } \\
\text { yang diambil } \\
\text { - Menutup kembali botol reagen }\end{array}$ & 4 \\
\hline & & 3 & Bila 2 kriteria terpenuhi & \\
\hline & & 2 & Bila 3 kriteria terpenuhi & \\
\hline & & 1 & Bila 1 kriteria terpenuhi & \\
\hline & $\begin{array}{l}\text { Partisipasi } \\
\text { selama } \\
\text { praktikum }\end{array}$ & 5 & $\begin{array}{l}\text { - Fokus pada kerja praktikum (tidak } \\
\text { melakukan } \\
\text { hal lain yang tidak ada hubungannya } \\
\text { dengan praktikum) } \\
\text { - Terlibat aktif selama kerja praktikum } \\
\text { - Ikut mengamati dengan teliti } \\
\text { - Ikut mencatat data praktikum dengan teliti } \\
\text { - Mampu bekerjasama dengan teman } \\
\text { sekelompok }\end{array}$ & 5 \\
\hline & & 4 & Bila 4 kriteria terpenuhi & \\
\hline & & 3 & Bila 2 kriteria terpenuhi & \\
\hline & & 2 & Bila 2 kriteria terpenuhi & \\
\hline & & 1 & Bila 1 kriteria terpenuhi & \\
\hline \multirow[t]{5}{*}{$\begin{array}{l}\text { Kegiatan } \\
\text { akhir } \\
\text { praktikum }\end{array}$} & \multirow[t]{5}{*}{$\begin{array}{l}\text { Penutup } \\
\text { praktikum }\end{array}$} & 4 & $\begin{array}{l}\text { - Memastikan peralatan dalam kondisi dan } \\
\text { posisi yang aman untuk ditinggalkan } \\
\text { - Merapikan peralatan dan botol-botol reagen } \\
\text { yang telah digunakan } \\
\text { - Membersihkan lingkungan praktikum } \\
\text { dari sampah } \\
\text { - Menyerahkan data hasil praktikum sementara }\end{array}$ & \multirow[t]{4}{*}{4} \\
\hline & & 3 & Bila 2 kriteria terpenuhi & \\
\hline & & 2 & Bila 3 kriteria terpenuhi & \\
\hline & & 1 & Bila 1 kriteria terpenuhi & \\
\hline & & & Skor maksimum & 31 \\
\hline
\end{tabular}

Mahasiswa dibagi ke dalam enam kelompok saat praktikum berlangsung. Aktivitas mahasiswa selama praktikum diobservasi oleh tiga orang observer dengan menggunakan lembaran rubrik kinerja praktikum. Setiap aktivitas praktikum yang ditampilkan oleh mahasiswa yang sesuai dengan kriteria penskoran diberi tanda centang $(\sqrt{ })$ pada lembaran rubrik. Selanjutnya tanda centang dihitung dan diberikan skor yang sesuai dengan ketentuan pada rubrik. Persentase kinerja praktikum untuk tiap sub-aspek dihitung dengan cara berikut:

$$
\text { Persentase }=\frac{\text { skor yang diperoleh }}{\text { skor maksimum }} \times 100
$$

Penentuan kategori kinerja praktikum untuk tiap sub-aspek mengacu pada panduan penilaian hasil belajar di institusi tempat penelitian yang disajikan pada Tabel 2. 
Tabel 2. Kategori Penilaian Kinerja Praktikum

\begin{tabular}{cc}
\hline Kriteria Kinerja & Interval Persentase \\
\hline Sangat Baik & $81-100$ \\
\hline Baik & $70-80$ \\
\hline Cukup Baik & $56-69$ \\
\hline Tidak Baik & $26-55$ \\
\hline
\end{tabular}

HASIL DAN PEMBAHASAN

Pengolahan data diawali dengan menghitung tanda centang $(\sqrt{ })$ pada lembaran rubrik kinerja dan ditetapkan skor untuk setiap sub-aspek. Selanjutnya skor pada masing-masing sub-aspek dihitung persentasenya. Rekapitulasi hasil rerata dan persentase setiap sub-aspek dapat dilihat pada Tabel 3.

Tabel 3. Rerata Skor Kinerja Praktikum pada Setiap Sub-Aspek

\begin{tabular}{llccc}
\hline \multicolumn{1}{c}{ Aspek } & \multicolumn{1}{c}{ Sub-aspek } & $\begin{array}{c}\text { Skor } \\
\text { Maks }\end{array}$ & $\begin{array}{c}\text { Rerata skor } \\
\text { perolehan } \\
(\%)\end{array}$ & $\begin{array}{c}\text { Kategori } \\
\text { Kinerja }\end{array}$ \\
\hline $\begin{array}{l}\text { Persiapan } \\
\text { praktikum }\end{array}$ & Perlengkapan keselamatan & 3 & $3(100)$ & Sangat Baik \\
\cline { 2 - 5 } & Rancangan praktikum & 2 & $1,88(94)$ & $\begin{array}{c}\text { Sangat } \\
\text { Baik }\end{array}$ \\
\cline { 2 - 5 } & Penggunaan sentrifus & 4 & $4(100)$ & Sangat Baik \\
\cline { 2 - 5 } $\begin{array}{l}\text { Penggunaan vortex } \\
\text { praktikum }\end{array}$ & $\begin{array}{l}\text { Penggunaan pipet mikro dan } \\
\text { tip }\end{array}$ & 6 & $3(100)$ & $\begin{array}{c}\text { Sangat } \\
\text { Baik }\end{array}$ \\
\cline { 2 - 5 } & $\begin{array}{l}\text { Pengambilan bahan kimia } \\
\text { (reagen) }\end{array}$ & 4 & $4(100)$ & $\begin{array}{c}\text { Sangat } \\
\text { Baik }\end{array}$ \\
\cline { 2 - 5 } & $\begin{array}{l}\text { Partisipasi selama } \\
\text { praktikum }\end{array}$ & 5 & $4,92(98,4)$ & Sangat Baik \\
\hline $\begin{array}{l}\text { Kegiatan } \\
\text { akhir praktikum }\end{array}$ & $\begin{array}{l}\text { Penutup praktikum } \\
\text { Jumlah }\end{array}$ & 4 & $3,96(99)$ & Sangat Baik \\
\hline
\end{tabular}

Data pada Tabel 3 menunjukkan secara keseluruhan kinerja praktikum mahasiswa dalam praktikum mengisolasi DNA berada pada kategori 'sangat baik' dengan rerata skor kinerja sebesar 97,23\%. Persentase kinerja praktikum tertinggi (100\%) terdapat pada sub-aspek 'perlengkapan keselamatan', 'penggunaan sentrifus', 'penggunaan vortex' dan 'pengambilan bahan kimia (reagen)'. Perolehan skor maksimum pada sub-aspek 'perlengkapan keselamatan' mengindikasikan bahwa seluruh mahasiswa praktikan menggunakan perlengkapan keselamatan di laboratorium, seperti jas laboratorium, sarung tangan, serta rambut tertutup atau tertata dengan rapi. Perolehan skor maksimum pada sub-aspek 'penggunaan sentrifus' dan 'penggunaan vortex mengindikasikan mahasiswa praktikan mampu menggunakan sentrifus dan vortex dengan baik dan benar. Perolehan skor maksimum pada sub-aspek 'pengambilan bahan kimia (reagen)' mengindikasikan mahasiswa mampu mengambil bahan kimia dengan benar dan tertib.

Selanjutnya, untuk sub-aspek 'penutup praktikum' persentasenya sebesar $99 \%$, hal ini terjadi karena ada satu kelompok yang tidak membersihkan meja mereka setelah kegiatan praktikum selesai. Persentase subaspek 'partisipasi selama praktikum' sebesar 98,4\%, karena ada mahasiswa yang tidak fokus dengan kegiatan praktikum. 
Persentase untuk sub-aspek 'rancangan praktikum' sebesar 94\%, seluruh mahasiswa menyiapkan dan memiliki rancangan praktikum sebelum praktikum dimulai, namun masih ada mahasiswa yang belum mempelajari rancangan praktikum, terbukti dengan tidak adanya coretan pada rancangan tersebut. Persentase 'penggunaan pipet mikro dan tip' sebesar $89,67 \%$; hal ini menunjukkan ada mahasiswa yang belum bisa memegang pipet serta memasangkan dan melepaskan tip dengan benar. Ada juga mahasiswa yang belum bisa memilih ukuran pipet yang sesuai dengan volume larutan yang akan diambil. Secara ringkas, kinerja mahasiswa dalam praktikum mengisolasi DNA pada setiap aspek disajikan pada Tabel 4.

Tabel 4. Rerata Persentase Kinerja Praktikum pada Setiap Aspek

\begin{tabular}{lcc}
\hline \multicolumn{1}{c}{ Aspek } & Rerata $(\%)$ & Kategori kinerja \\
\hline Persiapan praktikum & 97 & Sangat Baik \\
\hline Pelaksanaan praktikum & 97,61 & Sangat Baik \\
\hline Kegiatan akhir praktikum & 99 & Sangat Baik \\
\hline
\end{tabular}

Data pada Tabel 4 menunjukkan bahwa rerata setiap aspek kinerja praktikum berkategori 'sangat baik', dengan demikian dapat dinyatakan bahwa kinerja mahasiswa dalam praktikum mengisolasi DNA bakteri E. coli adalah 'sangat baik'.

Penggunaan asesmen kinerja berupa rubrik dalam penelitian ini memberikan keuntungan yaitu dapat mengases secara rinci aktivitas yang ditampilkan oleh setiap praktikan. Hal ini didukung oleh pernyataan Suryandari (2013) bahwa dengan rubrik yang lengkap kualitas dan profil kinerja peserta didik dapat diungkap dengan baik. Asesmen kinerja juga memberi kesempatan kepada peserta didik untuk menampilkan kemampuan yang sesungguhnya tanpa tekanan (Wulan, 2018).

Selanjutnya, dalam penelitian ini setiap observer mengamati praktikan sebanyak 9 orang (kelompok 1 dan 2), 10 orang (kelompok 3 dan 4) dan 7 orang (kelompok 5 dan 6) saat praktikum berlangsung. Penelitian lain yang mengembangkan instrumen asesmen kinerja untuk mengases kompetensi psikomotor siswa kelas XI SMA pada konsep hidrolisis garam menyimpulkan bahwa jumlah maksimum siswa yang diases sebanyak 6 orang tiap observasi (Nahadi, et al., 2016). Merujuk kepada hasil penelitian Nahadi, et al., (2016) tersebut berarti jumlah praktikan yang diamati oleh satu orang observer dalam penelitian ini kurang efektif karena lebih banyak.

\section{KESIMPULAN}

Berdasarkan analisis data dan pembahasan yang dipaparkan dapat disimpulkan bahwa kinerja mahasiswa dalam praktikum mengisolasi DNA adalah 'sangat baik' dengan rerata kinerja sebesar 97,23\%. Keterbatasan dalam penelitian ini adalah penilaian kinerja dilakukan terhadap individu mahasiswa yang melakukan aktivitas tertentu dan penilaian individu ini sekaligus menjadi penilaian untuk semua anggota di dalam kelompok tersebut. Hal tersebut dilakukan karena jumlah peralatan laboratorium yang sangat terbatas sehingga mahasiswa tidak dapat melakukan praktikum secara individu. Namun, untuk aspek penilaian yang sifatnya individual (tidak membutuhkan penggunaan peralatan laboratorium) maka penilaian dilakukan secara individu. Selain itu, tiap observer mengamati jumlah mahasiswa praktikan yang banyak (7-10 orang) sehingga pengamatan mungkin kurang efektif. Saran untuk penelitian selanjutnya adalah menganalisis hubungan antara kinerja praktikum dengan penguasaan konsep Isolasi DNA untuk mengetahui efektivitas praktikum. 


\section{DAFTAR PUSTAKA}

Campbell, N. A., dan Reece, J. B. (2010). Biologi Edisi 8 Jilid 3. Jakarta: Erlangga.

Fatchiyah, Arumingtyas, E. L., Widyarti, S., dan Rahayu, S. (2011). Biologi Molekular: Prinsip Dasar Analisis. Jakarta: Erlangga.

Glowinski, I., dan Bayrhuber, H. (2011). Student Labs on a University Campus as a Type of Out-Of-School Learning Environment: Assessing the Potential to Promote Students' Interest in Science. International Journal of Environmental and Science Education, Vol. 6, No. 4, pp. 371-392.

Membiela, P., dan Vidal, M. (2017). The Interest of the Diversity of Perspectives and Methodologies in Evaluating the Science Laboratory Learning Environment. EURASIA Journal of Mathematics Science and Technology Education, Vol. 13, No. 6, pp. 2069-2083. doi:

10.12973/eurasia.2017.01214a

Areepattamannil, S., Freeman, J. G., dan Klinger, D. A. (2011). Influence of Motivation, Self-Beliefs, and Instructional Practices on Science Achievement of Adolescents in Canada. Social Psychology of Education, Vol. 14, No. 2, pp. 233259. doi: 10.1007/s11218-010-9144-9.

Sedumedi, T. D. T. (2017). Practical Work Activities as a Method of Assessing Learning in Chemistry Teaching. EURASIA Journal of Mathematics
Science and Technology Education, Vol. 13, No. 6, pp. 1765-1784. doi: 10.12973/eurasia.2017.00697a.

Abrahams, I. dan Millar, R. (2008). Does Practical Work Really Work? A Study of the Effectiveness of Practical Work as a Teaching and Learning Method in School Science. International Journal of Science Education, Vol. 30, No. 14, pp. 1945-1969.

Cerini, B., Murray, I., dan Reiss, M. (2003). Student review of the science curriculum: Major findings. London: Planet Science/Institute of Education University of London/Science Museum. Accessed July 17, 2019 http://www.planetscience.com/sciteah/ review.

Suryandari, E. T. (2013). Performance Assessment sebagai Instrumen Penilaian untuk Meningkatkan Keterampilan Proses pada Praktikum Kimia Dasar di Tadris Kimia. Jurnal PHENOMENON, Vol. 3, No. 2, pp. 19-34.

Wulan, A. R. (2018). Menggunakan Asesmen Kinerja untuk Pembelajaran Sains dan Penelitian. Bandung: UPI Press.

Nahadi, Firman, H., dan Yulina, E. (2016). Performance Assessment Instrument to Assess the Senior High Students' Psychomotor for the Salt Hydrolysis Material. AIP Conference Proceedings 1708, 040005.

https://doi.org/10.1063/1.4941155 